\begin{tabular}{lc}
\hline CURRENT & ISSN: 0973-4929, Vol. 13, No. (3) 2018, Pg. 353-359 \\
WORLD & Current World Environment \\
ENVIRONMENT & Journal Website: www.cwejournal.org \\
\hline
\end{tabular}

\title{
Occupational Exposure of Noise Level in Opencast Iron Ore Mines in India
}

\author{
ANAND ARUN DESHMUKH ${ }^{1}$, SHIVKUMAR SHRINARAYAN PRAJAPATI ${ }^{\text {* }}$ \\ and RAHUL ANUP MISHRA ${ }^{1}$
}

${ }^{1}$ Department of Occupational Hygiene, National Institute of Miners' Health (NIMH), Autonomous Body Under Ministry of Mines, Government of India, JNARDDC Campus, Amravati Road,

Wadi Nagpur, Pincode-440023, India.

\begin{abstract}
Mining in general has become essential industry sector for the sustaining growth of any developing country. In India iron ore mining is mainly mechanised and well developed industry sector, using highly mechanised equipments and technology for excavation and processing of mined iron ore. It is due to this reason iron ore mining seen as a one of the major sector responsible for workplace occupational health hazard particularly for noise related health impacts on workers health. The objective of this study was to ascertain the job specific noise exposure among the Similar Exposure Groups (SEGs). Total 133 personal noise dosimeter samples were collected from different job category and working areas of iron ore mining and processing sector. It was observed that the participated workers in the crushing area were exposed to $81.64 \mathrm{~dB}(\mathrm{~A})$, Heavy Earth Moving Machineries (HEMM) operators $86.10 \mathrm{~dB}(A)$, loading plant workers $83.76 \mathrm{~dB}(\mathrm{~A})$, screening plant workers $87.62 \mathrm{~dB}(\mathrm{~A})$ and mines operation and workshop workers $84.92 \mathrm{~dB}(\mathrm{~A})$. During the study specifically HEMM operators were highly exposed to workplace noise, with $46 \%$ samples exceeding warning limit and $18 \%$ exceeding danger limit prescribed by Directorate General of Mines Safety (DGMS), Government of India. It was felt necessary to augment the awareness and safety training to the workers for proper implementation of preventive measure for workplace noise exposure.
\end{abstract}

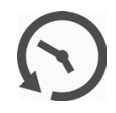

Article History

Received: 5 November 2018 Accepted: 22 December 2018

\section{Keywords}

India,

Mining,

Noise Exposure,

Occupational Health, Safety.

CONTACT Shivkumar Shrinarayan Prajapati 1 prajapatishiv1981@gmail.com $\mathbf{9}$ National Institute of Miners' Health (NIMH), Autonomous Body Under Ministry of Mines, Government of India, JNARDDC Campus, Amravati Road, Wadi Nagpur, Pincode-440023, India.

\section{(c) (i)}

(C) 2018 The Author(s). Published by Enviro Research Publishers.

This is an Open Access article licensed under a Creative Commons license: Attribution 4.0 International (CC-BY).

Doi: http://dx.doi.org/10.12944/CWE.13.3.08 


\section{Introduction}

The contribution of mining industry to the Indian economy is enormous; mining has contributed around $2.6 \%$ of Gross Domestic Product (GDP) in year of $2015-16$ with $20 \%$ contribution of mining of minerals. Industrial development in any country is driven by iron \& steel, because of the fact that it largely influences a country's economic status. ${ }^{1}$ The iron ore is an essential raw material used in the manufacturing of Iron \& Steel. Thus, mining of iron ore has become inevitable for any country. India is among the top producers of iron ore in the world with the total resources of over 33.276 billion tonnes. ${ }^{2}$ India is the third largest steel producer and fourth largest iron ore producer in the world. ${ }^{1}$ According to the data available with Indian Bureau of Mines (IBM), there were 296 reporting mines in 2016-17. Among them, 34 mines were in the public sector and 262 in the private sector. Mining leases of iron ore provides average daily employment to around 42,049 labours. $^{2}$

Iron ore mines in India are mostly mechanised mines. It is seen that extracted iron ore is further transported to the crusher unit for processing. Processing involves crushing, screening, and in some cases beneficiation. Noise is one of the important health and occupational hazard in the mining industry. Noise is regarded as the most typical health influencing harmful factor in both the countries North as well as South. ${ }^{3}$ A literature review conducted by Mirella Metidieri (2013) et al., it was concluded that "work-related hearing loss, particularly Noise Induced Hearing Loss (NIHL), is a highly prevalent occupational disease and a prominent occupational health hazard". ${ }^{4}$

Iron ore mining and processing is known to create noisy environment. Health damage caused by noise is very much related to the amount of acoustical energy (sound) received by hearing mechanism. The duration of noise exposure level and the susceptibility of the ear are primary factors for noise related hearing loss and injury. ${ }^{5}$ It is believed that noise causes disturbances in the ongoing activity and communication; addition to the direct health impacts such as Noise Induced Hearing Loss (NIHL). ${ }^{6,7}$ Prominent health effects due to occupational exposure to noise are lack of concentration, irritation, fatigue, and headache, sleep disturbances, etc. The risk is directly proportional to with the sound intensity, the length of time an employee is exposed to noise and the individual susceptibility to NIHL. ${ }^{8}$

Study conducted by Sunamani Kerketta (2012) et al., concluded that all the subjects studied in open cast chromium mines should be provided with the high frequency noise protective devices in particular HEMM operators. ${ }^{9}$ Another study conducted in South African mining industry showcased, that mean noise exposure levels was in the range from $63.9 \mathrm{dBA}$ to $113.5 \mathrm{dBA}$ and that counts approximately $73.2 \%$ of miners exposed to noise levels more than standard. ${ }^{10}$ Study conducted by National Institute for Occupational Safety and Health (NIOSH) in the coal industry revealed that more than $40 \%$ of all workers monitored were subject to noise exposures above $90 \mathrm{dBA}$ TWA ${ }_{8} .{ }^{11}$ The result of the study conducted by Shuchang Chen (2017) et al., indicated that occupational noise exposure is associated with higher levels of Systolic Blood Pressure (SBP), Diastolic Blood Pressure (DBP) and the risk of hypertension. ${ }^{12}$

In view of various safety concerns and probable number of workers directly exposed to workplace noise in iron ore mining, it was felt necessary to monitor the levels of personal noise exposure in iron ore mining and processing sector. Workers participated in the study were engaged in mining and processing of extracted iron ore. The objective of the current study was to measure the levels of workplace noise exposure of similar exposure groups (SEGs) to ascertain the job category wise exposure.

\section{Materials and Methods \\ Study Area}

The mine site is located in the Bailadila range which is around $120 \mathrm{Km}$ South-South-West (SSW) of Jagdalpur in Southern part of Dantewada district in the state of Chhattisgarh in India. The mine produces iron ore and placed topmost position in the public sector undertaking mining companies. The Bailadila Iron Ore Mines of National Mineral Development Corporations Limited (NMDC), Kirandul and Bacheli Complexes are approachable by road from Raipur and Vishakhapatnam. The general location of the study area is shown in Figure 1. 


\section{Mining and Processing}

Mining is carried out by fully mechanized open cast bench mining method with deployment of Heavy Earth Moving Machineries (HEMM) and in conjunction with deep hole blasting. Primary drilling is done by using $250 \mathrm{~mm}$ electrical blast hole rotary drills. Secondary drilling is done by $100 \mathrm{~mm}$ diameter crawler mounted drills for boulder drilling and toe drilling. Blasted material is loaded from the face by electric rope shovels (bucket capacity $4.6 \mathrm{~m}^{3}$ and $8 \mathrm{~m}^{3}$ ) and hydraulic excavator (bucket capacity $8 \mathrm{~m}^{3}$ ). Shovels load the material in to $85 / 100$ tone dumpers. The ore loaded into the dumpers is carried to the crushing plant, through the haul roads. The ore from crushing plant is transported to primary stockpile by belt conveyor system. Ore is further transported to screening plant by downhill conveyor system and up to the loading plant. Processed ore from loading plant stockpile is sent to Vishakhapattanam (Vizag) around 450 kilometers by rail route and to Raipur around 425 kilometers by road. Finished products are lump ore $(+10 \mathrm{~mm}$ to $-150 \mathrm{~mm})$, calibrated lump ore $(+10 \mathrm{~mm}$ to $-40 \mathrm{~mm})$ and fine ore $(-10 \mathrm{~mm})$.

\section{Sample Collection}

Present data were collected as a part of periodic workplace monitoring. Total one hundred thirtythree $(n=133)$ samples of personal noise exposure were collected. Workers were classified into several subgroups based on their workplace and their likely exposure to the source of noise. Consequently, Similar Exposure Group (SEGs) such as HEMM operators (dumper, dozer, shovel and drill), workers in the mining, and screening, crushing and workshops were included in the personal noise exposure study. SEGs are the categories of workers directly exposed to noise at workplace in iron ore mine and processing units. SEGs were asked to gather at the time office before going to their allotted work place. The purpose and aim of noise exposure sampling was narrated to them in a vernacular language. Noise pro DLX dosimeter were attached to the workers waist whereas, microphone were attached to the collar as high on the shoulder region away from the neck of all workers.

Personal noise exposure was measured using a Noise Pro DLX (Type -II) noise dosimeter manufactured by $3 \mathrm{MQuest}$ Technologies. The dosimeter used in the study is shown in Figure 2. The logging interval of the Noise Dosimeter was set at 1 minute with an Exchange Rate (ER) of $3 \mathrm{~dB}$ and with the "Slow" response in " $A$ " weighting. The dosimeter has a capability to store the data to memory, and can be viewed through the display screen. The equations

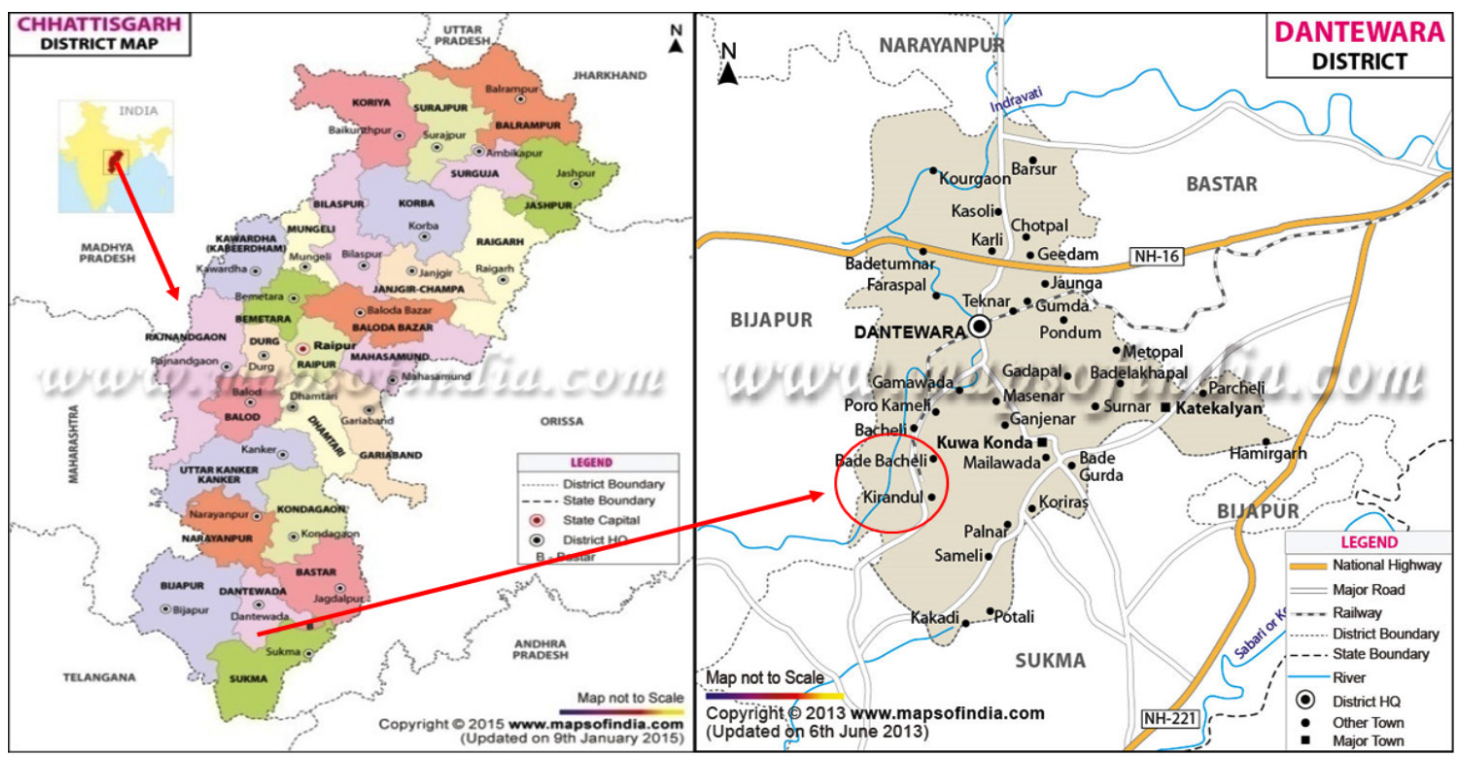

Fig. 1: General Location of the Study Area 


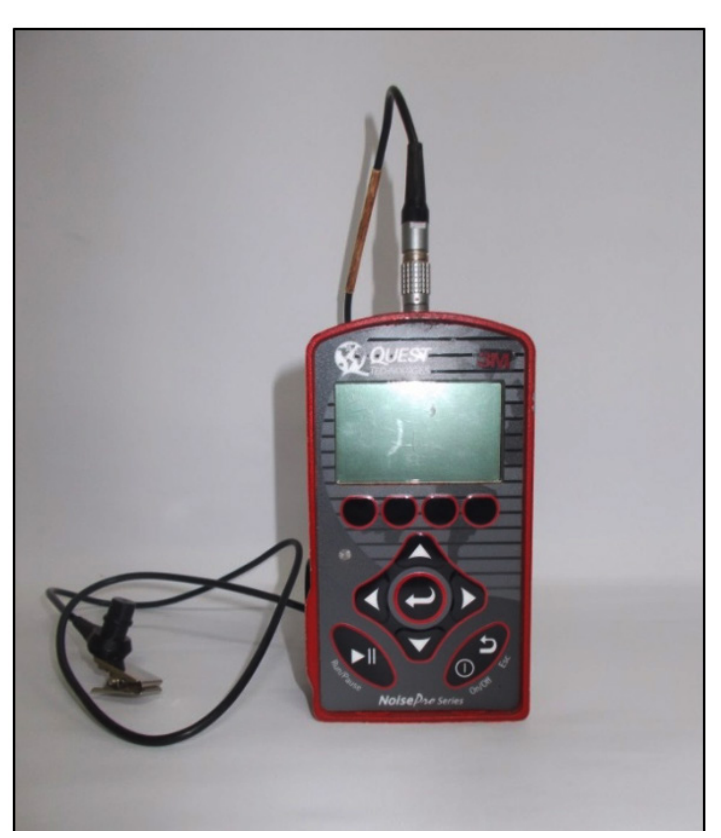

Fig. 2: Personal Noise Dosimeter used in the Noise Pro personal dosimeter for calculating the $\mathrm{TWA}_{8}$ values of noise levels exposure at workplace is given below. ${ }^{19}$

$$
\begin{aligned}
& T W A=E R\left[\log _{2} \int_{0}^{R T I M E} 2^{L S / E R} d t-\log _{2}(T C)\right] d B . \\
& T W A_{x \text { hours }}=L_{A V G}+\mathrm{ER}\left[\log _{2}\left(\frac{P r t}{T C}\right)\right] d B . \\
& \mathrm{ER}=\text { Exchange Rate }(3,4,5 \text { or } 6 \mathrm{~dB}) \\
& \text { Prt }=\text { Projection Time (seconds) } \\
& \mathrm{TC}=8 \text { Hours Criterion Time }(28800 \text { seconds) } \\
& \mathrm{RTIME}=\text { Run Time (seconds) } \\
& \mathrm{LS}=\text { Sound level, in decibels, that exceeds the } \\
& \text { Thresholds Level. The response time is indicated } \\
& \text { by the second letter (slow or fast). } \\
& \mathrm{CL}=\text { Criterion Level (40 to } 140 \mathrm{~dB})
\end{aligned}
$$

\begin{tabular}{|c|c|c|}
\hline Workplace of SEGs & Exposure to noise source & Specific function \\
\hline HEMM $(n=55)$ & $\begin{array}{l}\text { Dumper loading and } \\
\text { unloading, Crusher plant, } \\
\text { movement of dumper }\end{array}$ & $\begin{array}{l}\text { Dumper driver, Drill } \\
\text { operator, Shovel, Loader } \\
\text { and Dozer operators. }\end{array}$ \\
\hline Crushing plant $(n=28)$ & $\begin{array}{l}\text { Crushing of iron ore } \\
\text { into different sizes, } \\
\text { Dumper movements and } \\
\text { unloading of ore into hopper }\end{array}$ & $\begin{array}{l}\text { Crusher in charge, Supervisor } \\
\text { Dumper platform operators, } \\
\text { Crusher operators, MCO and } \\
\text { TCO, Crusher feeder }\end{array}$ \\
\hline Loading plant $(n=15)$ & $\begin{array}{l}\text { Wagon loading, Motor } \\
\text { operation, Wagon movement }\end{array}$ & $\begin{array}{l}\text { Feeder, Stacker, Reclaimer, } \\
\text { Motor room operator, } \\
\text { Maintenance assistant }\end{array}$ \\
\hline Screening plant $(n=23)$ & $\begin{array}{l}\text { Rotary screen, Screen } \\
\text { belt, Conveyor belts }\end{array}$ & $\begin{array}{l}\text { Conveyor operator, Motor } \\
\text { room operator, Fitter }\end{array}$ \\
\hline $\begin{array}{l}\text { Mines operation and } \\
\text { workshop }(n=12)\end{array}$ & $\begin{array}{l}\text { Mining activity, Workshop } \\
\text { maintenance activity }\end{array}$ & $\begin{array}{l}\text { Field attendant, Mining } \\
\text { supervisor Lathe machine } \\
\text { operator, Welder, }\end{array}$ \\
\hline
\end{tabular}

\section{Analysis}

Reading on the display screen after each sampling was noted down in the field sampling forms.

Table 1. Workplace of SEGs, noise sources and particular function of the SEGs 
A collected data was then organised and analysed using excel spread sheet. Data was cleaned and verified for any inconsistency against the original data recorded in the personal noise dosimeter and field sampling forms. In India Directorate General of Mines Safety (DGMS) circular no.18 Tech 75 has prescribed the permissible noise level of $90 \mathrm{~dB}(\mathrm{~A})$ in a shift of 8 hours for unprotected ear, whereas the "warning limit" as per DGMS has been fixed at $85 \mathrm{~dB}(\mathrm{~A})$ and $90 \mathrm{~dB}(\mathrm{~A})$ is the "danger limit". ${ }^{13}$

\section{Result and Discussion}

The details of SEGs workplace, noise source and specific job functions are analysed and presented in
Table 1. Average noise levels were observed during the study is presented in Table 2 .

There is no doubt that the majority of miners are exposed to hazardous levels of noise, ${ }^{14} \mathrm{~A}$ study conducted by Green (2015) et al., recorded personal noise exposure levels were $89.4 \mathrm{Leq}(\mathrm{dBA})$ in the mine work area and $92.4 \mathrm{Leq}(\mathrm{dBA})$ in the grinding or crushing area. ${ }^{15}$ Whereas in the present

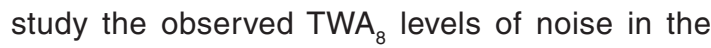
crushing area is $81.64 \mathrm{~dB}(\mathrm{~A}), \mathrm{HEMM}$ operators 86.10 $d B(A)$, loading plant $83.76 \mathrm{~dB}(A)$, screening plant $87.62 \mathrm{~dB}(\mathrm{~A})$ and mines operation and workshop workers $84.92 \mathrm{~dB}(\mathrm{~A})$.

Table 2. Workplace Average Noise Exposure Levels

\begin{tabular}{lccc}
\hline Workplace of SEGs & Lmin dB (A) & Lmax dB (A) & TWA8 dB (A) \\
\hline HEMM $(\mathbf{n = 5 5 )}$ & 63.39 & 114.47 & 86.10 \\
Crushing plant $(\mathrm{n}=\mathbf{2 8})$ & 61.48 & 113.73 & 81.64 \\
Loading plant $(\mathrm{n}=\mathbf{1 5})$ & 63.33 & 114.12 & 83.76 \\
$\begin{array}{l}\text { Screening plant }(\mathrm{n}=\mathbf{2 3}) \\
\text { Mines operation }(\mathrm{n}=\mathbf{1 2})\end{array}$ & 64.00 & 114.71 & 87.62 \\
\begin{tabular}{l} 
and workshop \\
\hline
\end{tabular}
\end{tabular}

Table 3. Percentage of SEGs exceed warning and danger limit

\begin{tabular}{lcc}
\hline Workplace of SEGs & $\begin{array}{c}\text { Exceed warning limit } \\
\mathbf{8 5 ~ d B ~ ( A )}\end{array}$ & $\begin{array}{r}\text { Exceed danger limit } \\
\mathbf{9 0} \mathbf{~ d B}(\mathbf{A})\end{array}$ \\
\hline HEMM $(\mathrm{n}=55)$ & $25(46 \%)$ & $10(18 \%)$ \\
Crushing plant $(\mathrm{n}=28)$ & $9(32 \%)$ & $3(11 \%)$ \\
Loading plant $(\mathrm{n}=15)$ & $9(60 \%)$ & $\mathrm{NIL}$ \\
Screening plant $(\mathrm{n}=23)$ & $8(35 \%)$ & $7(31 \%)$ \\
Mines operation and workshop $(\mathrm{n}=12)$ & $4(34 \%)$ & $1(9 \%)$ \\
\hline
\end{tabular}


In the present study, HEMM operators are highly exposed to workplace noise, with $46 \%$ samples exceeding warning limit and $18 \%$ exceeding danger limit. Crushing plant operation considered to be most noise generating process in the mining industry, though number of workers exceeding statutory limits is less as compare to HEMM. This may have been due to the fact that workers in the crusher plant usually isolate themselves from the noise source at the moment of peak exposure. Whereas, HEMM operators moves around the mines and cannot isolate themselves from the multiple source of noise exposure; it was observed that workers usually keep side window of the cabin opened. The movement of dumpers during the study were from different benches to crusher plant, waste dump area. Workers exposed to noise more than $85 \mathrm{~dB}$ (A) are more exposed to elevated blood pressures, ${ }^{16}$ this may hamper workers ability to perform their task and exposed them to higher risk of accidents and workplace noise health hazard. Crushing plant operators are exposed to workplace noise with $32 \%$ samples exceeding warning limit and $11 \%$ exceeding danger limit. Screening plant and mines operation workshop workers with $35 \%$ and $34 \%$ samples exceeding warning limit and $31 \%$ and $9 \%$ exceeding danger limit respectively. None of the workers from loading plant were found to exceed danger limit whereas $60 \%$ exceeded warning limit. From our study 76 workers out of total 133 are at higher risk of noise related workplace health hazards.

Study conducted by A. K. Gorai and A. K. Pal (2006) in the same iron ore mining complex, investigated the noise impact in the surrounding residential area. It was concluded that colony residents near tertiary crushing plant were more dissatisfied $(45.71 \%)$. Overall, the noise stress of resident found to be much higher $(0.19)$ than that of the indicative noise impact index (0.083).17 Though, exposure to noise in mining environment is being difficult to control and NIHL has remains the common health hazard, ${ }^{18}$ preventive measure is the only solution that can best suitable in the prevailing discussion of avoiding an workplace noise exposure and its adverse health impacts.

\section{Conclusion}

1. It is concluded that, $55(41 \%)$ samples were crossed the warning limit but below the danger limit and 21 samples (16\%) workers were exceed the danger limit out of 133 participated in the workplace noise monitoring as prescribed by DGMS.

2. There are typical observations during the study which reflects the casual attitude of the workers towards workplace hazard.

3. Workers are found to be uncomfortable using ear muffs, dumper shovel and dozer operators keep side windowpane opened during working for better natural ventilation.

4. It is recommended that, precautionary measure such as personal protective equipments, periodical rotation in the job task and workplace, timely health check-up specifically audiometry test should be performed.

5. Detailed job specific (task based) exposure assessment needs to be carried out in the mining environment to ascertain the extent and degree of exposure.

6. It is recommended that mines owner should implement an awareness generation and occupational safety training periodically in order to prevent workers from the exposure to high noise levels.

\section{Conflict of Interest}

The authors declare that they have no conflict of interest.

\section{Acknowledgements}

Authors thankfully acknowledge the participation of project team during field study. Authors declares that the contents, including any opinion and conclusion expressed, are solely those of the authors alone and do not necessarily reflect the policy of institution of affiliation. 


\section{References}

1. Government of India. www.makeinindia. com. http://www.makeinindia.com/article/-/v/ sector-survey-mining. Accessed August 28, 2018.

2. Indian Bureau of Mines. Indian Minerals Yearbook 2015. Indian Miner Yearb2015 (PartIII Miner Rev. 2016;54th Editi (November):1-9. doi:10.1007/BF0322074

3. Zare S., Baneshi MR., Hemmatjo R., Ahmadi S., Omidvar M., Dehaghi BF. The Effect of Occupational Noise Exposure on Serum Cortisol Concentration of Night-shift Industrial Workers: A Field Study. Saf Health Work. 2018:5-9. doi:10.1016/j.shaw.2018.07.002.

4. Metidieri MM., Santos Rodrigues HF., De Oliveira Filho FJMB., Ferraz DP., De Almeida Neto AF., Torres S. Noise-Induced Hearing Loss (NIHL): Literature review with a focus on occupational medicine. Int Arch Otorhinolaryngol. 2013;17(2):208-212. doi:10.7162/S1809-97772013000200015.

5. Sen T., Bhattacharjee PK., Banerjee D., Sarkar B. Study and Comparison of the Noise Dose on Workers in a Small Scale Industry in West. 2010;1(4).

6. Stansfeld SA, Matheson MP. Noise pollution: Non-auditory effects on health. Br Med Bull. 2003;68(August):243-257. doi:10.1093/bmb/ Idg033.

7. Prasanna Kumar G., Dewangan K., Sarkar A. Noise exposure in oil mills. Indian J Occup Environ Med. 2008;12(1):23. doi:10.4103/0019-5278.40812.

8. Nandi S., Dhatrak S. Occupational noiseinduced hearing loss in India. Indian J Occup Environ Med. 2008;12(2). doi:10.4103/001952743260.

9. Sunamani Kerketta., Rajendra Gartia SB. Occupational hearing loss of the workmen of an open cast chromite mines. Indian J Occup Env Med. 2012;16(1):18-21.
10. Edwards AL., Dekker JJ., Franz RM., Van Dyk T., Banyini A. Profiles of noise exposure levels in South African mining. J South African Inst Min Metall. 2011.

11. Babich DR., Bauer ER., Vipperman JR. Equipment Noise and Worker Exposure in the Coal Mining Industry. United States Natl Inst Occup Saf Heal (NIOSH), Dec 2006, 85 pp. 2006.

12. Chen S., Ni Y., Zhang L., et al., Noise exposure in occupational setting associated with elevated blood pressure in China. BMC Public Health. 2017;17(1):1-7. doi:10.1186/ s12889-017-4050-0.

13. L. C. Kaku., D. G. M. S. Circulars. Dhanbad: Lovely Prakashan; 20

14. McBride DI. Noise-induced hearing loss and hearing conservation in mining. Occup Med (Chic III). 2004;54(5):290-296. doi:10.1093/ occmed/kqh075.

15. Green A., Jones AD., Sun K., Neitzel RL. The association between noise, cortisol and heart rate in a small-scale gold mining community-a pilot study. Int J Environ Res Public Health. 20 doi:10.3390/ijerph120809952.

16. Nserat S., Al-Musa A., Khader YS., Abu Slaih A., Iblan I. Blood pressure of jordanian workers chronically exposed to noise in industrial plants. Int J Occup Environ Med. 2017;8(4):217-223. doi:10.15171/ ijoem.2017.1134.

17. Gorai AK., Pal AK. Noise impact assessment of an iron ore mining complex. Noise Control Eng J. 2006;54(6):352. doi:10.3397/1.2375034.

18. Donoghue AM. Occupational health hazards in mining: An overview. Occup Med (Chic III). 2004;54(5):283-289. doi:10.1093/occmed/ kqh072.

19. NoisePro ${ }^{\mathrm{TM}}$ user manual.3M Occupational health and environmental safety division NoisePro ${ }^{\mathrm{TM}}$ personal noise dosimeter.2010;84. 